\title{
ПРОГНОЗУВАННЯ МОДИФІКАЦІЇ ПРИРОДНИХ КОМАРИНИХ ОСЕРЕДКІВ ОСОБЛИВО НЕБЕЗПЕЧНИХ ІНФЕКЦІЙ В УКРАЇНІ ПІД ВПЛИВОМ КЛІМАТИЧНИХ ЗМІН
}

\author{
Львівський національний медичний університет імені Данила Галицького МОЗ України
}

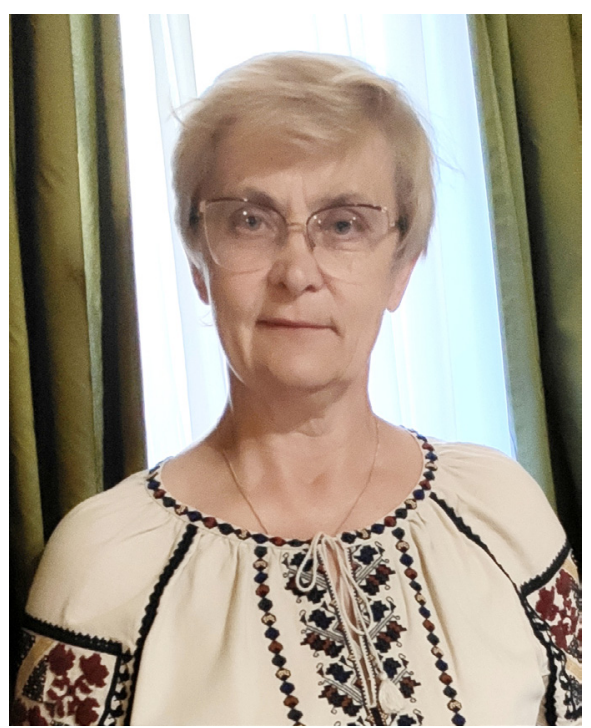

Початок нового тисячоріччя ознаменувався суттєвим зростання рівнів біологічних небезпек і загроз, незважаючи на прогрес і нові досягнення у боротьбі з інфрекційними хворобами. Зміна кліматичних умов 3 тенденцією до збільшення середньобагаторічних температур зумовила перерозподіл і структурні зміни в ареалах поширення біологічних видів тварин, птахів, рептилій та багатьох інших компонентів, які фрормують паразитарні системи зооантропонозів. Просторові зміни ензоотичних територій з переформатуванням суперареалів зумовили зростання ризиків ураження населення збудниками особливо небезпечних природно-осередкових інфекцій та інвазій.

З урахуванням існуючих тенденцій змін низки епідеміологічно значимих абіотичних і біотичних чинників, проаналізовано наявні та потенційні загрози для України внаслідок змін клімату й обумовлених цим просторових змін природних осередків, їх тривалості фрункціонування, появи нових збудників. Прогнозується поява нових патогенів і формування активних автохтонних природних і змішаних осередків комариних трансмісивних інфекцій, переважно дифруного типу. $€$ висока ймовірність укорінення на території держави нових збудників або високовірулентних генетичних варіантів ендемічних патогенів. Потенційну небезпеку становлять збудники гарячок Чикунгун'я, денге, Зіка, Західного Нілу (нові генотипи), а також малярії.

Територіями ризику поширення гарячок денге, Чикунгун'я, а також малярії будуть АР Крим, Луганська, Донецька, Запорізька, Миколаївська, Херсонська, Одеська, Чернівецька і Закарпатська області. Гарячка Західного Нілу розширить ареал з охопленням північних територій у зоні Полісся, а також є реальна загроза заміни цього збудника у західному регіоні на високовірулентний нейроінвазивний генотип внаслідок поширення останнього з території Румунії. Група комариних інсрекцій стане домінуючою серед трансмісивних природно-осередкових інфрекцій з переважанням полігостальних осередків.

Ключові слова: особливо небезпечні інфекції, природні осередки, клімат, прогнозування.

Територія України за географічними, кліматичними, фрлоро-фрауністичними характеристиками є сприятливою для орормування природних осередків особливо небезпечних інорекцій (OHI). Структура паразитарних систем може суттєво різнитися в регіонах і клімато-географрічних зонах залежно від стацій різноманітних видів птахів і тварин, які можуть бути резервуарами збудників, а також широкого спектра векторів, що беруть участь у передачі збудників інфекційних захворювань. Багаторічні дослідження на території держави від 50-х років минулого сторіччя виявили циркуляцію низки патогенних біологічних агентів (ПБА) з групи зооантропонозів. Було вивчено ареали їх поширення, епізоото-епідеміологічні закономірності вірусного кліщового енцефраліту, туляремії, лептоспірозу, гарячки Західного Нілу, геморагічної гарячки з нирковим синдромом тощо [1-7]. 
Також було встановлено важливе значення птахів - дальніх мігрантів у занесенні з інших держав і територій збудників ОНІ. У зв'язку з цим територіями ризику поширення нових варіантів збудників ОНІ були визначені регіони, над якими проходять трансконтинентальні коридори перелітних птахів [8, 9]. До раніше вивчених арбовірусних інфекцій, які поширювалися з перелітними птахами, в останні роки додалися високопатогенні віруси грипу [10].
Протягом останніх років на території України спостерігаються зміни меж і структури ареалів природноосередкових ОНІ, що переважно зумовлено суттєвим антропогенним впливом на природні ландшафти (табл. 1), зміною кліматичних умов внаслідок глобального потепління, низкою інших компонентів процесів глобалізації [11].

Зіставлення антропогенних чинників з потенційними їх наслідками впливу на трансмісивні природно-осередкові інфрекції [12]

\begin{tabular}{|l|l|}
\hline \multicolumn{1}{|c|}{ Антропогенний чинник } & \multicolumn{1}{|c|}{ Потенційний наслідок впливу } \\
\hline Вирубування лісів, видобування корисних копалин & Зміна ареалів поширення резервуарів і векторів, їх видів \\
\hline Осушення & Зміна екосистем \\
\hline Туризм, торгівля & Інтродукція збудників і векторів \\
\hline Урбанізація & $\begin{array}{l}\text { Створення оптимальних умов для виплоду векторів (Aedes aegypti). } \\
\text { Формування антропургічних осередків }\end{array}$ \\
\hline $\begin{array}{l}\text { Будівництво рекреаційних комплексів, створення } \\
\text { штучних водойм }\end{array}$ & Модисрікація природних осередків, їх структури \\
\hline $\begin{array}{l}\text { Розвиток птахівництва і конярства, завезення } \\
\text { екзотичних тварин і птахів }\end{array}$ & $\begin{array}{l}\text { Нові резервуари } \\
\text { Нові території ризику }\end{array}$ \\
\hline
\end{tabular}

Особливе занепокоєння викликає зміна температури в загальнопланетарному масштабі. Так, за даними Всесвітньої метеорологічної організації, впродовж останніх 130 років температура у світі збільшилась приблизно на $0,85^{\circ} \mathrm{C}$, а за минулі 25 років темпи потепління стрімко зросли. Відповідно, змінюється характер і кількість атмосферних опадів, що призводить до змін гідрологічних параметрів територій. Все це сприяє зна- чному подовженню сезонів передачі трансмісивних інфекцій, зміні їх географрічних зон поширення та структури осередків $[12,13]$. Прогнозується подальше зростання температури, що призведе до просторових змін клімато-географрічних зон. Ймовірний сценарій розвитку ситуації в Європі з урахуванням часових проміжків наведено на малюнку 1.
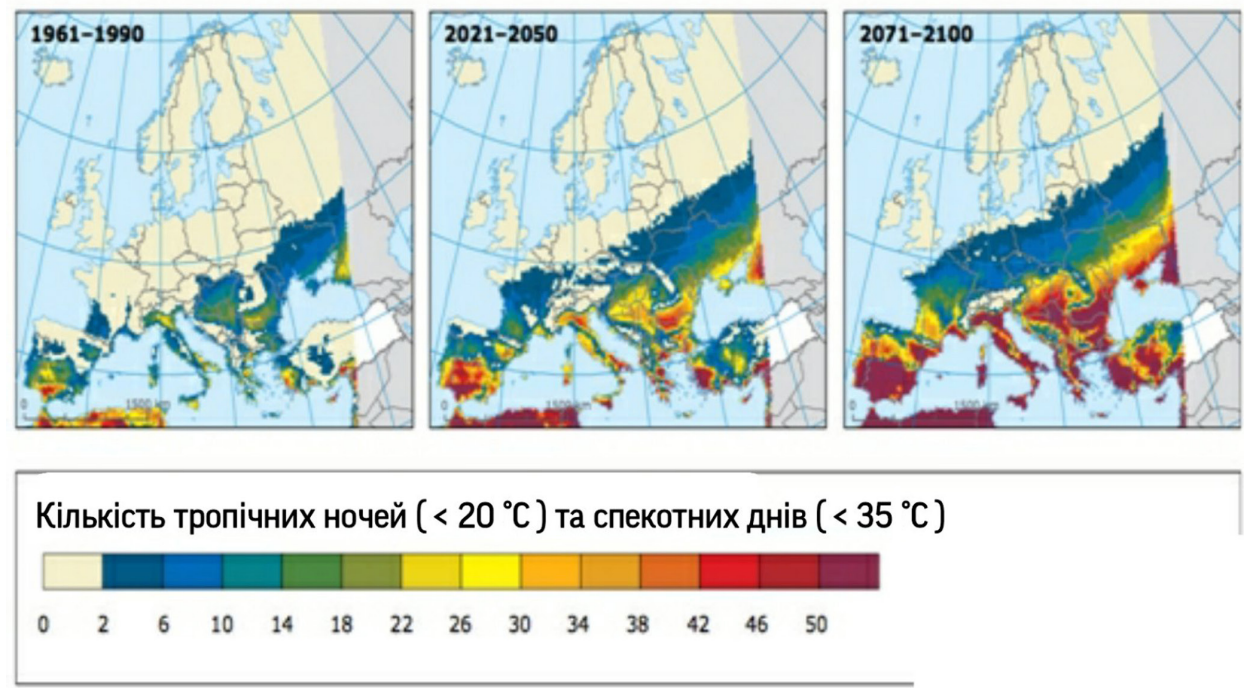

Мал. 1. Тенденції у змінах клімату на планеті [14]. 
Разом з тим, стрімкі процеси глобалізації, розвиток інфраструктури, зокрема інтенсивне будівництво рекреаційних комплексів, створення штучних водойм сприяють зміні ландшафтів, заводненості територій, зміні структури екосистем, а також фрормують нові умови, де потенційно може відбуватись або припинятися виплід специфічних векторів, як визначальної ланки трансмісивних інфекцій $[15,16]$. Хоча абіотичні складові є вкрай розмаїтими, їх вплив реалізується через біотичні складові паразитарних систем і модифікуються соціальними чинниками (мал. 2).

Ці ж чинники будуть порушувати екологічні зв'язки птахів водно-болотного комплексу, стабільність ареалів тварин-резервуарів, які фрормують природні та змішані осередки нетрансмісивних ОНІ [17].

\section{Біотичні}

резервуари, вектори, сприйнятлива популяція
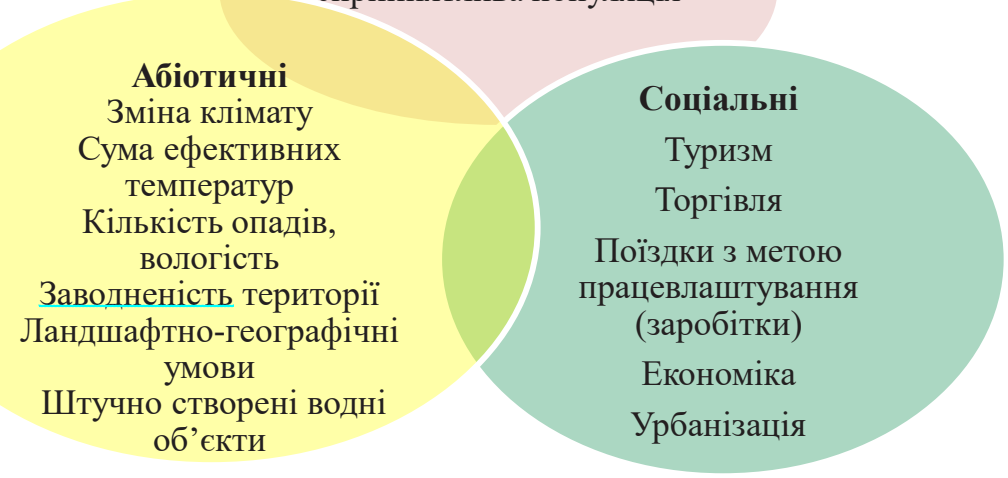

Мал. 2. Комплекс біотичних, абіотичних і соціальних чинників, що модифікують природні осередки трансмісивних особливо небезпечних інсрекцій.

Визначальними параметрами у фрормуванні осередків OHI є сума ефективних температур, що забезпечує повноцінні цикли розвитку векторів збудників іноекцій, заводненість території та інші еколого-орлористичні умови, необхідні для метаморфозу і відтворення векторів комариних і кліщових інфекцій. Наступною важливою складовою $€$ фауністичні комплекси, як базис існування біологічних видів - резервуарів збудників інфекцій. Сумарно ці показники визначають просторові характеристики ареалів циркуляції патогенних біологічних агентів 3 трансмісивним механізмом передачі патогенів [18-20].

Еволюція інтродукції чотирьох основних збудників комариних трансмісивних інорекцій на європейський континент свідчить про зростання і розширення спектру біологічних загроз у цьому регіоні, як і в цілому на планеті. Так, на європейському континенті автохтонний осередок вірусу Чикунгун'я виявлено у серпні 2007 р. [21]. Місцева обмежена передача збудника гарячки денге вперше встановлена у 2010 р. [22, 23], вірусу Зіка - у серпні 2019 р. [24]. Загроза повернення малярії, ерадикація якої в Європі сталася в середині XX сторіччя, є реальною у XXI сторіччі [25].
На планеті спостерігається тенденція до зростання середньорічних температур, що впливає на ареали поширення трансмісивних інфекцій, значна частка 3 яких належить до групи ОНІ. Встановлено, що підвищення температури на $1{ }^{\circ} \mathrm{C}$ зміщує межу клімато-географічних зон у середньому на 100 км на північ [13].

Впродовж останніх років середньорічна температура в Україні зросла на $2^{\circ} \mathrm{C}$, що зумовило зміщення меж кліматичних зон у різних регіонах на 150-200 км. Так, Херсонщина, південні частини Запорізької, Миколаївської та Одеської областей за сумою температур наблизилися до субтропіків, а зона Полісся звузилася до декількох кілометрів (мал. 3). За прогнозами Всесвітньої метеорологічної організації, середньорічна температура в Україні до 2100 року може підвищитись на 3,2-4,5 º. Подібна тенденція спостерігається у всіх європейських країнах [26].

У сукупності кліматичні зміни і процеси глобалізації мають вагомий вплив на розширення меж відомих природних осередків у світі та в Україні, а також сприяють поширення далеко за їх межі низки актуальних природно-осередкових ОНІ: вірусного кліщового енцесраліту, 
зоонозних бореліозів і рикетсіозів, гарячок денге, Чикунгун'я, Синдбіс, Західного Нілу, жовтої гарячки, малярії, москітних гарячок, чуми тощо. Визначальним чинником функціонування таких осередків $€$ наявність компетентних векторів. Найчутливішими до впливу температурного чинника у цій групі $€$ комарині ОНІ, оскільки від цього залежить їх видовий і кількісний склад $[18,28]$. Моделювання розвитку епізоото-епідемічного процесу внаслідок кліматичних змін, що було здійснене
євроCDC, свідчить про однонаправленість процесів розширення у північному напрямку ензоотичних територій з комариних трансмісивних інфекцій. Враховувалося, що європейські популяції Aedes albopictus володіють високою векторною спроможністю до поширення інших арбовірусів - гарячки Західного Нілу, Зіка, Синдбіс, жовтої гарячки та інших, коли вважалося, що їх основними векторами є комари роду Culex [29].

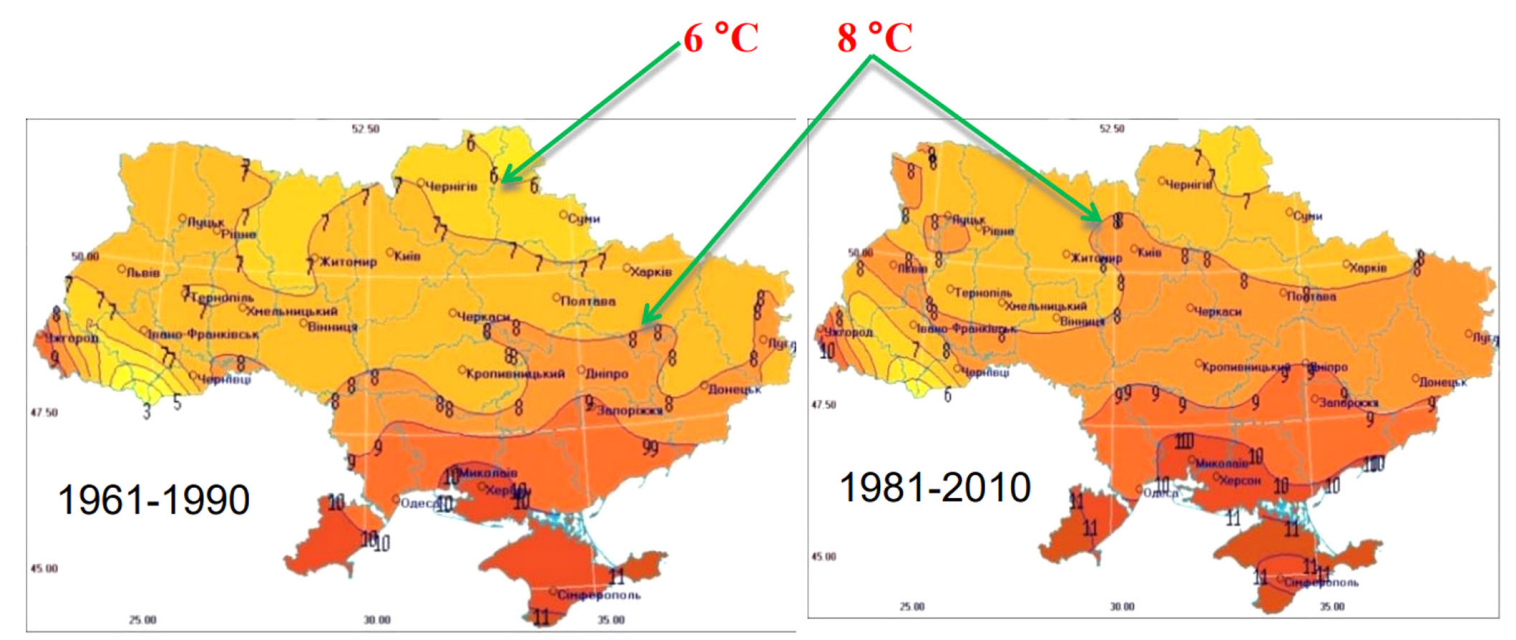

Мал. 3. Середньорічна приземна температура повітря у базовий (1961-1990) та сучасний (1981-2010) кліматичні періоди [27].

В Україні, як і в інших країнах Європи, комарі родів Aedes та Culex € актуальними ефективними векторами, а посеред них найбільше епідеміологічне значення, як вектори ОНІ, мають Aedes albopictus i Aedes aegypti.

Моделювання ризиків просторової кліматичної спроможності поширення вірусу гарячки Чикунгун'я комарами Aedes albopictus було здійснено з урахуванням масштабних спалахів хвороби в Албанії, Італії, Індії та інших країнах, а також поточного і прогностичного значення середньомісячної температури в різних країнах Європи впродовж різних періодів часу [28]. Встановлено, що середнє значення температури $20-22^{\circ} \mathrm{C}$ впродовж не менше як одного місяця $є$ мінімальним порогом, що визначає ризик до поширення вірусу гарячки Чикунгун'я комарами Aedes albopictus, а значення $26^{\circ} \mathrm{C}$ підвищує такий ризик у рази. Дані щодо прогнозу просторових змін територій ризику поширення гарячки Чикунгун'я для країн європейського регіону наведено на малюнку 4.

Беручи до уваги подібності клімато-географрічних характеристик у нашій державі до країн центральної Європи, можемо передбачити формування ензоотичних осередків гарячки Чикунгун'я в АР Крим до 2040 р., ймовірність поширення збудника на території п'яти областей північно-причорноморського регіону. Більша частина України буде у зоні високого ризику формування стабільних осередків цієї ОНІ до 2070 р.

В інших дослідженнях вивчено ризики укорінення в Європі гарячки денге до 2100 р., з урахуванням максимальних і мінімальних температурних параметрів, показників вологості, кількості опадів, а також векторної спроможність комарів Aedes aegypti та Aedes albopictus як основних епідеміологічно значимих векторів [30]. Результати моделювання засвідчили, що Середземноморські регіони Південної частини Європи та країни Західної Європи перебувають у найвищій зоні ризику (мал. 5).

Отже, як свідчать наукові дослідження з прогнозування ризиків поширення комариних ОНI, до середини XXI століття буде спостерігатися значне розширення меж ареалів циркуляції комариних арбовірусних інфекцій на європейському континенті, а малярія знову може стати автохтонним паразитозом.

На підставі аналізу тенденцій змін температурних показників у нашій державі, а також з використанням методології інтерполяції даних за принципом подібності та відмінності процесів в екосистемах, з урахуванням просторових характеристик і видового складу актуальних комариних інфекцій передбачаємо поширення і 


\section{ПЕРЕДОВА СТАТТЯ}

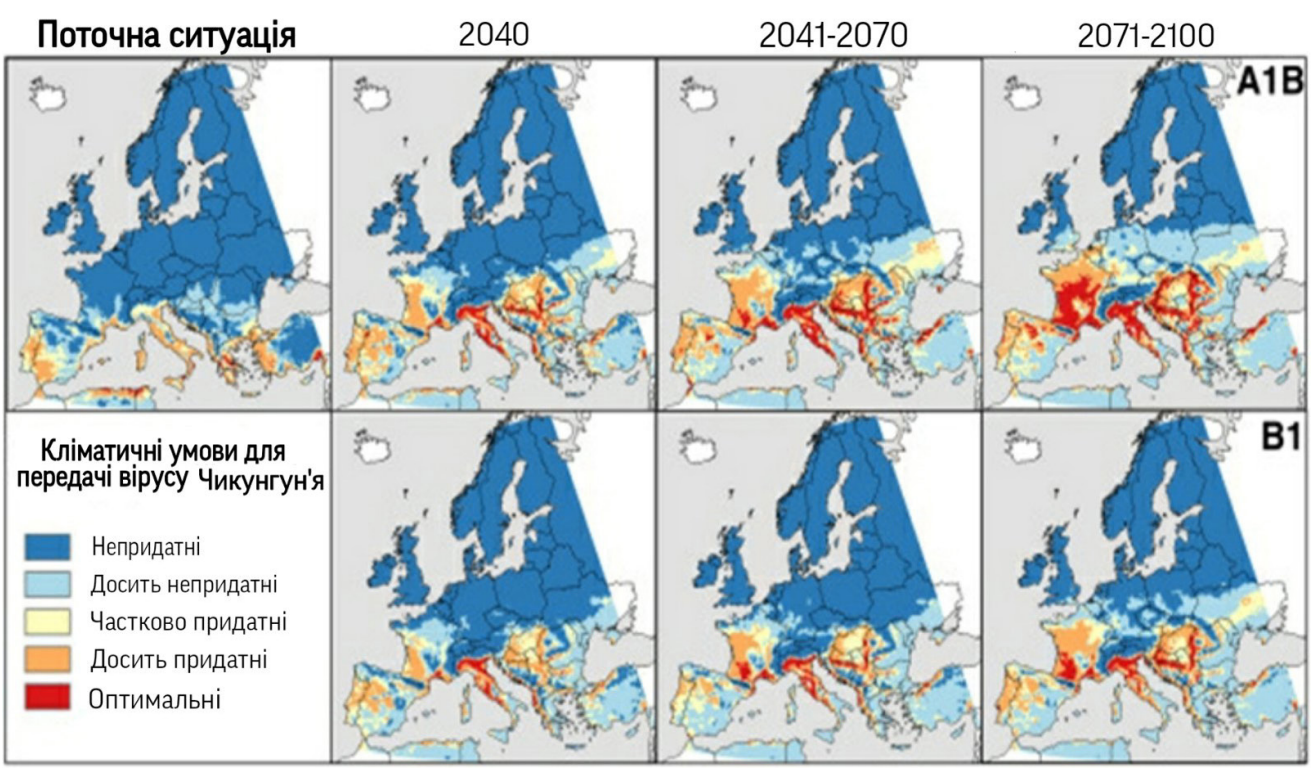

Мал. 4. Моделювання ризиків просторової кліматичної спроможності поширення вірусу гарячки Чикунгун'я в Європі комарами Aedes albopictus [30].

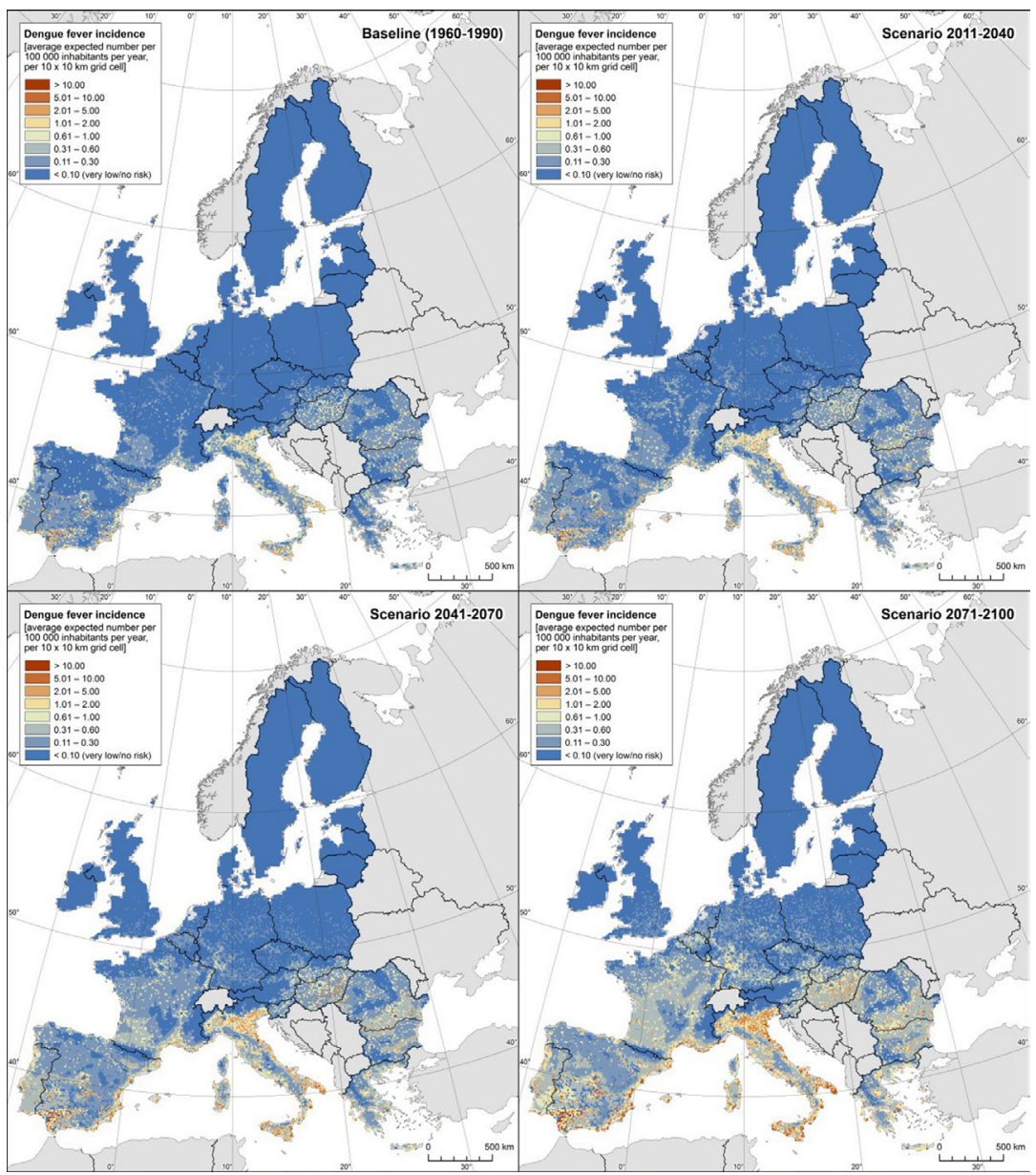

Мал. 5. Прогноз поширення гарячки денге у країнах європейського союзу до 2100 р. [31]. 
укорінення в Україні низки нових збудників ОНІ. Територіями ризику поширення гарячок денге, Чикунгун'я, а також малярії будуть АР Крим, Луганська, Донецька, Запорізька, Миколаївська, Херсонська, Одеська, Чернівецька і Закарпатська області. Гарячка Західного Нілу розширить ареал з охопленням північних територій у зоні Полісся, а також $є$ реальна загроза заміни цього збудника у західному регіоні на високовірулентний нейроінвазивний генотип внаслідок поширення останнього з території Румунії. Група комариних трансмісивних інсекцій стане домінуючою серед трансмісивних природно осередкових інфекцій з переважанням полігостальних осередків.
Означений нами сценарій зміни епізоото-епідемічного потенціалу комариних трансмісивних інфекцій та інвазій зумовлює необхідність запровадження активного комплексного епідеміологічного нагляду, що має включати медичний, ветеринарний, епізоотологічний, ентомологічний, гідрологічний, зоологічний, лабораторний вірусологічний, мікробіологічний і паразитологічний блоки у режимі постійного моніторингу, використання геоінорормаційних систем і кліматичних прогностичних моделей для адекватного захисту населення та території України від цього виду біологічних загроз.

\section{Література}

1. Виноград И.А. Арбовирусы в Украинской ССР и их медико-биологическое значение: Автореф. дисс. ... д-ра мед. наук / И.А. Виноград, Львовский медицинский институт. - Львов, 1983. - 21 с.

2. Василишин 3.П. Лабораторна діагностика кліщового енцесраліту та іксодового кліщового бореліозу серед населення ендемічних територій: дис. ... канд. мед. наук: 03.00.06 / Василишин Зоряна Петрівна, Нац. мед. ун-т ім. О.О. Богомольця. - К., 2008. $-174 \mathrm{c}$.

3. Козак Л.П. Сучасні аспекти вірусологічної діагностики геморагічної гарячки з нирковим синдромом: дис. ... канд. мед. наук: 03.00.06 / Козак Людмила Петрівна, Нац. мед. ун-т ім. О.О. Богомольця. - К., 2008. - 174 с.

4. Юрченко О.О. Трансмісивні вірусні інсрекції Північно-Західного Причорномор'я: дис. ... канд. біол. наук: 03.00.06 / Юрченко Оксана Олександрівна, Нац. мед. ун-т ім. О.О. Богомольця. - К., 2013. - 240 c.

5. Комаренко Н.С. Мікроорганізми в біоценотичних структурах природних осередків кліщових трансмісивних зооантропонозів: автореф. дис. ... канд. біол. наук: 03.00.07 / Комаренко Наталія Сергіївна; НАН України, Ін-т біології клітини. - Львів, 2014. - 22 с.

6. Шуль У.А. Епідеміологічні особливості гарячки Західного Нілу та оптимізація системи епідеміологічного нагляду на ендемічних територіях: дис. ... канд. мед. наук: 14.02.02 / Шуль Уляна Андріївна, ДУ «Інститут епідеміології та інфекційних хвороб ім. Л.В. Громашевського НАМН України». - К., 2017. - 163 с.

7. Евстафьев И.Л. Клещевой энцефалит в Крыму (итоги 20-летнего изучения) // Мед. паразитология и паразитарные болезни. - 2001. - № 2. - С. 53-57.

8. Львов Д.К. Миграции птиц и перенос возбудителей инсекций (эколого-геограсрические связи птиц с возбудителями инфекций) / Д.К. Львов, В.Д. Ильичев. - М.: Наука, 1979. - 271 с.

9. Серебряков В.В. Екологічні закономірності міграції птахів фауни України в часі та просторі: дис. ... д-ра біол. наук: 03.00.16 / Серебряков Валентин Валентинович, Київський національний ун-т ім. Тараса Шевченка. - К., 2002. - 486 с.

10. Pathogenic assessment of avian influenza viruses in migratory birds / E.-H. Kim, Y. Kim, S.M. Kim [et al.] // Emerg Microbes Infect. - 2021. - Vol. 10, N 1. - P. 565-577. Access mode: doi: 10.10 80/22221751.2021.1899769.
11. Виноград Н.О. Арбовірусні інсекції Північно-Західного Причорномор'я / Н.О. Виноград, О.О. Юрченко, Д.О. Дубіна // Інсрекційні хвороби. - 2013. - № 3. - С. 5-9.

12. Fouque F. Impact of past and on-going changes on climate and weather on vector-borne diseases transmission: a look at the evidence / F. Fouque // Infectious Diseases of Poverty. - 2019. - Vol. 8. - P. 51. Access mode: https://doi.org/10.1186/s40249-019-0565-1.

13. Paz S. Climate change impacts on vector-borne diseases in Europe: Risks, predictions and actions / S. Paz // The Lancet Regional Health Europe. - 2021. - Vol. 1. Access mode: doi:https:// doi.org/10.1016/j.lanepe.2020.100017.

14. Grist. The 16 scariest maps from the E.U.'s massive new climate change report. https://grist.org/climate-energy/the-16-scariestmaps-from-the-e-u-s-massive-new-climate-change-report/

15. Ecosystem perspectives are needed to manage zoonotic risks in a changing climate / R. Gibb, L. Franklinos, D.W. Redding, K.E. Jones // BMJ (Clinical research ed.). - 2020. - Vol. 371. - P. 3389. Access mode: https://doi.org/10.1136/bmj.m3389.

16. Forecasting zoonotic infectious disease response to climate change: mosquito vectors and a changing environment / A.W. Bartlow, C. Manore, C. Xu [et al.] // Veterinary Sciences. - 2019. - Vol. 6 (2). - P. 40. Access mode: https://doi.org/10.3390/vetsci6020040.

17. Aguirre A.A. Changing Patterns of Emerging Zoonotic Diseases in Wildlife, Domestic Animals, and Humans Linked to Biodiversity Loss and Globalization / A.A. Aguirre // ILAR Journal. 2017. - Vol. 58 (3). - P. 315-318. Access mode: https://doi.org/10.1093/ ilar/ilx035.

18. Bellone R. The Role of Temperature in Shaping MosquitoBorne Viruses Transmission / R Bellone, A.B. Failloux // Front. Microbiol. - 2020. - Vol. 11. Access mode: https://doi.org/10.3389/ fmicb.2020.584846.

19. Do we know how mosquito disease vectors will respond to climate change? / R.F. Andriamifidy, N.B. Tjaden, C. Beierkuhnlein, S.M. Thomas // Emerg. Top. Life Sci. - 2019. - Vol. 3 (2). - P. 115-132. Access mode: doi: 10.1042/ETLS20180125. PMID: 33523151.

20. Chala B. Feyissa Hamde Emerging and Re-emerging VectorBorne Infectious Diseases and the Challenges for Control: A Review / B. Chala, F. Hamde // Frontiers in Public Health. - 2021. - Vol. 9. Access mode: https://doi.org/10.3389/fpubh.2021.715759. 
21. European Centre for Disease Prevention and Control Mission Report Chikungunya in Italy. Joint ECDC / WHO visit for a European risk assessment, 17-21 September. - 2007. Access mode: https://www.ecdc.europa.eu/sites/default/files/media/en/publications/ Publications/0709_MIR_Chikungunya_in_Italy.pdfChikungunya in Italy).

22. Autochthonous dengue fever in Croatia, August-September 2010 / I. Gjenero-Margan, B. Aleraj, D. Krajcar [et al.] // Euro Surveill. - 2011. - Vol. 16 (9). Access mode: PMID: 21392489.

23. Dengue virus infection in a traveller returning from Croatia to Germany / J. Schmidt-Chanasit, M. Haditsch, I. Schöneberg [et al.] // Euro Surveill. - 2010. - Vol. 15 (40). - Access mode: https://doi. org/10.2807/ese.15.40.19677-en.

24. Vector-borne transmission of Zika virus in Europe, southern France, August 2019 / S. Giron, F. Franke, A. Decoppet [et al.] // Euro Surveill. - 2019. - Vol. 24 (45). Access mode: https://doi. org/10.2807/1560-7917.ES.2019.24.45.1900655.

25. Malaria in Europe: A Historical Perspective / M.A. Boualam, B. Pradines, M. Drancourt, R. Barbieri // Frontiers in medicine. 2021. - Vol. 8. - 691095. Access mode: https://doi.org/10.3389/ fmed.2021.691095.

26. Climate Impacts in Europe Under $+1.5{ }^{\circ} \mathrm{C}$ Global Warming / D. Jacob, L. Kotova, C. Teichmann [et al.] // Earth's
Future. - 2018. - Vol. 6. - P. 264-285. Access mode: https://doi org/10.1002/2017EF000710

27. Зміна клімату в Україні та світі: причини, наслідки та рішення для протидії // Екодія. https://ecoaction.org.ua/zmina-klimatuua-ta-svit.htm

28. Teixeira M.G. Zika, chikungunya and dengue: the causes and threats of new and re-emerging arboviral diseases / M.G. Teixeira, L.C. Rodrigues // BMJ Glob Health. - 2018. - Vol. 3 (1). Access mode: doi:10.1136/bmjgh-2017-000530.

29. Competence of Aedes aegypti, Ae. albopictus, and Culex quinquefasciatus Mosquitoes as Zika Virus Vectors, China / Z. Liu, T. Zhou, Z. Lai [et al.] // Emerging infectious diseases. - 2017. Vol. 23 (7). - P. 1085-1091. Access mode: https://doi.org/10.3201/ eid2307.161528.

30. Modelling the effects of global climate change on Chikungunya transmission in the $21^{\text {st }}$ century / N.B. Tjaden, J.E. Suk, D. Fische [et al.] // Sci. Rep. - 2017. - Vol. 7. - P. 3813. Access mode https://doi.org/10.1038/s41598-017-03566-3.

31. Climate change and the emergence of vector-borne diseases in Europe: case study of dengue fever / M. Bouzid, F.J. Colón-González, T. Lung [et al.] // BMC Public Health. - 2014. - Vol. 4. - P. 781. Access mode: doi: 10.1186/1471-2458-14-781.

\section{References}

1. Vynohrad, I.A. (1983). Arboviruses in the Ukrainian SSR and their medico-biological significance. Extended abstract of D Med Sci dissertation (Medical Sciences). Lviv National Medical University, Lviv [in Russian].

2. Vasylyshyn, Z.P. (2008). Laboratory diagnostic of tick-borne encephalitis and Ixodes tick-borne borreliosis among the population of endemic areas. Candidate's thesis. O.O. Bohomolets National Medical University, Kyiv [in Ukrainian]

3. Kozak, L.P. (2008). Modern aspects of virological diagnosis of hemorrhagic fever with renal syndrome. Candidate's thesis. O.O. Bohomolets National Medical University, Kyiv [in Ukrainian].

4. Yurchenko, O.O. (2013). Transmissible viral infections of the North-Western Black Sea coas. Candidate's thesis. O.O. Bohomolets National Medical University, Kyiv [in Ukrainian].

5. Komarenko, N.S. (2014). Microorganisms in biocoenotic structures of natural foci of tick-borne transmissible zooanthroponoses. Candidate's thesis. Institute of Biology Cell, Lviv [in Ukrainian].

6. Shul, U.A. (2017). Epidemiological features of West Nile fever and optimization of the system of epidemiological surveillance in endemic areas. Candidate's thesis. SI "L.V. Hromashevskyi Institute of Epidemiology and Infectious Diseases National Academy of Medical Sciences of Ukraine", Kyiv [in Ukrainian].

7. Evstafyev, I.L. (2001). Tick-borne encephalitis in Crimea (results of a 20-year study). Medycynskaya parazitologiya i parazitarnye bolezni - Medical Parasitology and Parasitic Diseases, 2, 53-57 [in Russian].

8. Lvov, D.K., \& llyichev, V.D. (1979). Bird migration and transfer of infectious agents (ecological and geographic connections of birds with infectious agents). Moscow [in Russian].

9. Serebriakov, V.V. (2002). Ecological regularities of birds migration of fauna in Ukraine in time and space. Candidate's thesis. Taras Shevchenko Kyiv National University, Kyiv [in Ukrainian].
10. Kim, E.-H., Kim, Y., Kim, S.M., Yu, K.M., Casel, M.A., Jang, S., Choi, Y.K. (2021). Pathogenic assessment of avian influenza viruses in migratory birds. Emerg. Microbes Infect., 10 (1), 565-577. Retrieved from: DOI: 10.1080/22221751.2021.1899769.

11. Vynohrad, N.O., Yurchenko, O.O., \& Dubina, D.O. (2013). Arboviral infections of the North-Western Black Sea coast. Infectsiini khvoroby - Infectious Diseases, 3, 5-9 [in Ukrainian].

12. Fouque, F., \& Reeder, J. C. (2019). Impact of past and on-going changes on climate and weather on vector-borne diseases transmission: a look at the evidence. Infectious Diseases of Poverty, 8 (1), 1-9.

13. Paz, S. (2021). Climate change impacts on vectorborne diseases in Europe: Risks, predictions and actions. The Lancet Regional Health Europe, 1. Retrieved from: doi:https://doi. org/10.1016/j.lanepe.2020.100017.

14. Grist. The 16 scariest maps from the E.U.'s massive new climate change report. Retrieved from: https://grist.org/climate-energy/ the-16-scariest-maps-from-the-e-u-s-massive-new-climate-changereport/

15. Gibb, R., Franklinos, L., Redding, D. W., \& Jones, K. E. (2020). Ecosystem perspectives are needed to manage zoonotic risks in a changing climate. BMJ (Clinical Research ed.), 371, m3389. Retrieved from: https://doi.org/10.1136/bmj.m3389.

16. Bartlow, A.W., Manore, C., Xu, C., Kaufeld, K. A., Del Valle, S., Ziemann, A., Fairchild, G. and Fair, J.M. (2019). Forecasting zoonotic infectious disease response to climate change: mosquito vectors and a changing environment. Veterinary Sciences, 6 (2), 40. Retrieved from: https://doi.org/10.3390/vetsci6020040.

17. Aguirre, A.A. (2017). Changing patterns of emerging zoonotic diseases in wildlife, domestic animals, and humans linked to biodiversity loss and globalization. ILAR Journal, 58 (3), 315-318. Retrieved from: https://doi.org/10.1093/ilar/ilx035. 
18. Bellone, R., \& Failloux, A.B. (2020). The role of temperature in shaping mosquito-borne viruses transmission. Front. Microbiol., 11. Retrieved from: https://doi.org/10.3389/fmicb.2020.584846

19. Andriamifidy, R.F., Tjaden, N.B., Beierkuhnlein, C., \& Thomas, S.M. (2019). Do we know how mosquito disease vectors will respond to climate change? Emerg. Top Life Sci., 3 (2), 115-132. Retrieved from: doi: 10.1042/ETLS20180125. PMID: 33523151

20. Chala, B., Hamde, F. (2021). Emerging and re-emerging vector-borne infectious diseases and the challenges for control: A Review. Frontiers in Public Health, 9. Retrieved from: https://doi. org/10.3389/fpubh.2021.715759.

21. European Centre for Disease Prevention and Control (2007). Mission Report Chikungunya in Italy. Joint ECDC / WHO visit for a European risk assessment, 17-21 September, 2007. Retrieved from: https://www.ecdc.europa.eu/sites/default/files/media/en/publications/ Publications/ 0709_MIR_Chikungunya_in_Italy.pdfChikungunya inltaly).

22. Gjenero-Margan, I., Aleraj, B., Krajcar, D., Lesnikar, V., Klobučar, A., Pem-Novosel, I. ... Mlinarić-Galinović, G. (2011). Autochthonous dengue fever in Croatia, August-September 2010. Euro Surveill, 16(9):19805. PMID: 21392489.

23. Schmidt-Chanasit, J., Haditsch, M., Schöneberg, I., Günther, S., Stark, K., Frank, C. (2010). Dengue virus infection in a traveller returning from Croatia to Germany. Euro Surveill., 15 (40), 19677. Retrieved from: https://doi.org/10.2807/ese.15.40.19677-en.

24. Giron, S., Franke, F., Decoppet, A., Cadiou, B., Travaglini, T., Thirion, L. ... Leparc-Goffart, I. (2019). Vector-borne transmission of Zika virus in Europe, southern France, August 2019. Euro Surveill., 24(45), 1900655. Retrieved from: https://doi.org/10.2807/1560-7917. ES.2019.24.45.1900655.

\section{FORECASTING THE MODIFICATION OF NATURAL MOSQUITO-BORNE FOCI OF EXTREMELY DANGEROUS INFECTIONS IN UKRAINE UNDER THE INFLUENCE OF CLIMATE CHANGE}

N.O. Vynohrad, U.A. Shul

Danylo Halytskyi Lviv National Medical University

SUMMARY. The beginning of the new millennium was marked by a significant increase in the levels of biological hazards and threats, despite the progress and new advances in the fight against infectious diseases. Changes in climatic conditions with a tendency to increase the average long-term temperatures have led to redistribution and structural changes in the habitats of biological species of animals, birds, reptiles and many other components that form the parasitic systems of zooanthroponoses. Spatial changes in enzootic territories with the reformatting of superareas have led to an increased risk of affection the population by
25. Boualam, M.A., Pradines, B., Drancourt, M., \& Barbieri, R. (2021). Malaria in Europe: A Historical Perspective. Frontiers in Mmedicine, 8, 691095. Retrieved from: https://doi.org/10.3389/ fmed.2021.691095.

26. Jacob, D., Kotova, L., Teichmann, C., Sobolowski, S.P., Vautard, R., Donnelly, C., ... van Vliet, M.T.H. (2018), Climate impacts in Europe under $+1.5^{\circ} \mathrm{C}$ global warming. Earth's Future, 6: 264-285. Retrieved from: https://doi.org/10.1002/2017EF000710

27. Climate change in Ukraine and the world: causes, consequences and solutions to counter. Ecodia. Retrieved from: https://ecoaction.org.ua/zmina-klimatu-ua-ta-svit.html

28. Teixeira, M.G., \& Rodrigues, L.C. (2018). Zika, Chikungunya and dengue: the causes and threats of new and re-emerging arboviral diseases. BMJ Glob Health., 3 (1), 000530. Retrieved from: doi:10.1136/bmjgh-2017-000530.

29. Liu, Z., Zhou, T., Lai, Z., Zhang, Z., Jia, Z., Zhou, G., ... Chen, X. G. (2017). Competence of Aedes aegypti, Ae. albopictus, and Culex quinquefasciatus Mosquitoes as Zika Virus Vectors, China. Emerging Infectious Diseases, 23 (7), 1085-1091. Retrieved from: https://doi. org/10.3201/eid2307.161528.

30. Tjaden, N.B., Suk, J.E., Fischer, D., Beierkuhnlein, C., \& Semenza, J. (2017). Modelling the effects of global climate change on Chikungunya transmission in the $21^{\text {st }}$ century. Sci. Rep., 7, 3813. Retrieved from: https://doi.org/10.1038/s41598-017-03566-3.

31. Bouzid, M., Colón-González, F.J., Lung, T., Lake, I.R., \& Hunter, P.R. (2014). Climate change and the emergence of vectorborne diseases in Europe: case study of dengue fever. BMC Public Health,14, 781. Retrieved from: doi: 10.1186/1471-2458-14-781. pathogens of extremely dangerous natural focal infections and invasions.

It is carried out the analysis of real and potential threats to Ukraine due to climate change and the resulting spatial changes of natural foci, their functional duration and the emergence of new pathogens with taking into account the existing trends of changes in a number of epidemiologically significant abiotic and biotic factors. The emergence of new pathogens and the formation of active natural and mixed foci of mosquito-borne transmissible infections, mainly of the diffuse type, is predicted. There is a high probability of rooting in the state territory of new pathogens or highly virulent genetic variants of endemic agents. Potential dangers are the pathogens of fevers - Chikungunya, dengue, Zika, West Nile (new genotypes), and also malaria.

Risk areas of dengue fever, Chikungunya, as well as malaria will be the Autonomous Republic of Crimea, Luhansk, Donetsk, Zaporizhia, Mykolaiv, Kherson, Odesa, Chernivtsi and Zakarpattia regions. West Nile 


\section{ПЕРЕДОВА СТАТТЯ}

fever will expand the range to cover the northern territories in the Polissia area, and there is a real threat of replacing this pathogen in the western region with a highly virulent neuroinvasive genotype due to the spread of it from the Romania territory. The group of mosquitoborne infections will become dominant among transmissible natural focal infections with a predominance of polyhostal foci.

Key words: extremely dangerous infections; natural foci; climate; forecasting.

\section{Відомості про авторів:}

Виноград Наталія Олексіївна - профресорка, д. мед. н., Львівський національний медичний університет імені Данила Галицького, завідувачка кафедри епідеміології; e-mail: vynogradno@ukr.net
Шуль Уляна Андріївна - к. мед. н., Львівський національний медичний університет імені Данила Галицького, асистентка кафредри епідеміології; e-mail: pylichka83@gmail. com

\section{Information about the authors:}

Vynohrad N.O. - Professor, MD, Danylo Halytskyi Lviv National Medical University, Head of the Epidemiology Department; e-mail: vynogradno@ukr.net

Shul U.A. - PhD, Danylo Halytskyi Lviv National Medical University, Assistant of the Epidemiology Department; e-mail: pylichka83@gmail.com

Конфрлікт інтересів: немає.

Authors have no conflict of interest to declare.

Отримано 4.09.2021 p. 